\title{
Peningkatan Keterampilan Menulis Letter of Opinion (Surat Opini) pada Mata Pelajaran Bahasa Inggris dengan Menggunakan Media Fantastic Card di Kelas XI
}

\section{Improving the Skill of Writing Letter of Opinion in English Subject Using Fantastic Card in the $11^{\text {th }}$ Grade}

\author{
Atiek Indriyastuti \\ SMA Negeri 7 Semarang, Kota Semarang \\ atiekindriyastuti15@gmail.com
}

Riwayat Artikel: Dikirim 21 September 2018; Diterima 27 Juni 2019; Diterbitkan 30 Juni 2019

\begin{abstract}
ABSTRAK
Tujuan Penelitian ini adalah untuk mengetahui sejauh mana peningkatan keterampilan siswa dalam menulis letter of opinion di Kelas XI. Penelitian ini dilakukan pada kelas XI-IPS-2 SMA Negeri 15 Semarang semester 1 Tahun Pelajaran 2017-2018 sebagai hasil penggunaan media fantastic card. Penelitian ini juga digunakan untuk mengetahui sejauh mana peningkatan pengetahuan dan sikap belajar siswa selama pembelajaran. Metode yang digunakan dalam penelitian ini adalah metode Penelitian Tindakan Kelas dengan teknik siklus yang terdiri dari dua tindakan siklus yaitu siklus 1 dan siklus 2. Alat pengumpulan data yang digunakan untuk data kuantitatif berupa tes tertulis ulangan harian dan data kualitatif digunakan lembar observasi atau pengamatan, lembar refleksi diri, lembar penilaian antar teman, dan rubrik penilaian kinerja. Hasil penelitian menunjukkan media fantastic card dapat meningkatkan keterampilan menulis letter of opinion. Ketuntasan Belajar mengalami peningkatan dari kondisi awal 53,13\% menjadi 65,63\% pada siklus I dan meningkat menjadi $93,75 \%$ pada siklus II. Peningkatan keterampilan siswa dalam menulis letter of opinion pada siklus I mencapai $2,53 \%$ dari ratarata hasil belajar pada pra siklus dan hasil belajar pada siklus II mengalami peningkatan sebesar $6,81 \%$ dari rata-rata hasil belajar pada siklus I atau mengalami peningkatan sebesar 9,34\% jika dibandingkan dengan rata-rata hasil belajar pada pra siklus.
\end{abstract}

Kata kunci: menulis, letter of opinion, media fantastic card

\begin{abstract}
This research was aimed to find out the extent of students' skill at writing letter of opinion in $11^{\text {th }}$ grade. The research was conducted in the $11^{\text {th }}$ Grade of Social Science 2at Public Senior High School 15 Semarang in Academic Year 2017-2018 after using fantastic
\end{abstract}


card. It was to know the improvement of knowledge and attitude of the students during learning. Method used was class action research method with cycle technique consisting of two cycles, i.e. cycle 1 and cycle 2. Instruments of data taking were written daily tests and as for qualitative data, observation sheet, self-reflection sheet, peer evaluation sheet, and performance evaluation rubric were used. Results of the research showed that fantastic card could improve the skill of writing letter of opinion. The learning completeness improved from $53.13 \%$ to $65.63 \%$ in cycle I, and $93.75 \%$ in cycle II. The students' skill in writing letter of opinion in cycle I improved up to $2.53 \%$ from the average learning result in pre-cycle. Meanwhile, th elearning result in cycle II improved as much as $6.81 \%$ from the average learning result in cycle I, or $9.34 \%$, compared to the average learning result in pre-cycle.

Keywords: writing, letter of opinion, media fantastic card

\section{PENDAHULUAN}

\section{Latar Belakang}

Untuk dapat menguasai keterampilan menulis dengan baik, seorang penulis harus dapat (1) menemukan masalah yang akan ditulis untuk dijadikan topik;(2) menentukan pembaca (audience) yang manakah tulisan tersebut ditujukan;(3)membuat rancangan (draft) karangan, dimana setiap teks memiliki masing-masing struktur atau susunan teks sesuai dengan kegunaan teks tersebut; (4) memiliki kemampuan menggunakan bahasa yang terdiri dari berbagai aspek seperti pemakaian kosa kata yang tepat, tata bahasa yang baik dan benar, penggunaan ejaan dan tanda baca yang benar; (5) menguasai kemampuan memulai sebuah paragraf yang akan ditulisnya dengan topik atau pokok bahasan yang dikembangkan menjadi kalimat sehingga akhirnya menjadi sebuah paragraf yang bermakna;(6) memiliki kemampuan memeriksa tulisan (editing).

Hasil pengamatan pada kelas XI-IPS-2 SMA Negeri 15 Semarang menunjukkan siswa memiliki prestasi yang kurang memuaskan. Pada pokok bahasan menulis letter of opinion pada awalnya tidak ada siswa yang mendapatkan nilai amat baik yaitu dari rentang nilai 86-100 dan hanya 7 siswa yang mendapatkan nilai baik yaitu dari rentang nilai 76-85 dari 32 orang siswa. Siswa yang mendapatkan nilai cukup yaitu rentang 70-75 ada 10 siswa, ada 13 siswa mendapatkan nilai kurang dan ada 2 siswa mendapatkan nilai sangat kurang. Sehingga prosentase ketuntasan secara klasikal pada kelas XI-IPS-2 tergolong masih sangat kurang yaitu 53,13\%.

Siswa kelas XI-IPS-2 menganggap bahwa keterampilan menulis letter of opinion dalam Bahasa Inggris sulit sekali. Hal ini disebabkan karena ada beberapa aspek kebahasaan (misalnya : pemakaian kosa kata yang tepat, tata bahasa yang baik dan benar, penggunaan ejaan dan tanda baca yang benar) 
yang harus dikuasai siswa apabila ia ingin terampil menulis teks berbahasa Inggris. Penulis merasa kurang maksimalnya presentase ketuntasan minimal secara klasikal dikarenakan guru belum menggunakan media pembelajaran yang menarik.

Berdasarkan latar belakang diatas, maka peneliti berusaha mencari alternatif media pembelajaran yang menyenangkan dalam menyajikan materi letter of opinion dengan harapan dapat meningkatkan keterampilan menulis siswa. Media pembelajaran yang dipilih untuk penelitian ini adalah media fantastic card. Dengan media fantastic card siswa diharapkan dapat meningkatkkan keterampilannya menulis letter of opinion. Media fantastic card ini dirancang oleh siswa sendiri sehingga tampak unik, menarik dan membantu siswa dalam memunculkan ide-idenya.

\section{Identifikasi Masalah}

Berlatar belakang masalah yang telah dikemukakan diatas, teridentifikasi 2 (dua) permasalahan sebagai berikut : (1) keterampilan menulis teks siswa masih rendah, sehingga diharapkan setelah menggunakan media fantastic card keterampilan menulis siswa terutama dalam menulis letter of opinion meningkat. (2) guru peneliti belum menggunakan media fantastic card dalam mengajarkan keterampilan menulis letter of opinion. Diharapkan tindakan tersebut akan meningkatkan keterampilan menulis siswa terutama dalam menulis letter of opinion.

\section{Rumusan Masalah}

Secara spesifik permasalahan ini dapat dirinci menjadi perumusan masalah penelitian yakni: Bagaimanakah pembelajaran dengan menggunakan media fantastic card dapat meningkatkan keterampilan siswa dalam menulis letter of opinion pada siswa kelas XI-IPS-2 SMA Negeri 15 Semarang Tahun Pelajaran 2017/2018?

\section{Tujuan}

Penelitian ini bertujuan untuk mendeskripsikan peningkatan keterampilan menulis letter of opinion menggunakan media fantastic card pada siswa kelas XI-IPS-2 SMA Negeri 15 Semarang Tahun Pelajaran 2017/2018. 


\section{Hakikat Menulis}

Slameto (2010) menyampaikan bahwa belajar ialah suatu proses usaha yang dilakukan seseorang untuk memperoleh suatu perubahan tingkah laku yang baru secara keseluruhan, sebagai hasil pengalamannya sendiri dalam interaksi dengan lingkungannya. Definisi tersebut menekankan bahwa belajar adalah sebuah proses, artinya belajar tidak dilakukan secara singkat melainkan terus menerus (continu). Belajar adalah usaha, yang dilakukan oleh individu untuk menjadi lebih baik, dan merupakan hasil dari perilaku sebelumnya yang berupa pengalaman.

Sementara Surya (1997) dalam Rusman (2015), menjelaskan bahwa belajar sebagai suatu proses yang dilakukan oleh individu untuk memperoleh perubahan prilaku secara keseluruhan, sebagai hasil dari pengalaman pribadi itu sendiri dalam interaksi dengan lingkungannya. Suraya menjelaskan bahwa belajar adalah proses, artinya bahwa belajar adalah hasil dari sebuah tindakan yang dilakukan atau tidak tiba-tiba berubah. Lebih lanjut belajar itu merupakan suatu tindakan yang disengaja. Tindakan yang disengaja itu adalah untuk mencapai perubahan yang bertujuan.

Rusman (2015) berpendapat bahwa belajar merupakan salah satu faktor yang mempengaruhi dan berperan penting dalam pembentukan pribadi dan perilaku individu. Pendapat tersebut menempatkan belajar sebagai faktor dalam pembentukan karakter dan perilaku. Pembentukan pribadi dan prilaku seseorang sangat dipengaruhi oleh kegiatan belajarnya, misal dia tidak dapat belajar dengan baik, maka akan menghasilkan pembentukan pribadi dan prilaku tidak baik begitupun sebaliknya.

\section{Letter of Opinion (Surat Opini)}

Fungsi sosial dari teks jenis ini adalah untuk menyampaikan keluhan atau opini mengenai sesuatu kepada publik.

$\begin{array}{ll}\text { Struktur umum (Generic structure) } \quad: & \text { - Menyatakan sesuatu hal } \\ & \text { kepada publik } \\ & \text { - } \text { Memberikan opini dan ide mengenai } \\ & \text { sesuatu kepada publik } \\ : & - \text { meminta dan memberi opini dan ide } \\ & \text { - Menyetujui atau tidak menyetujui } \\ & \text { opini dan ide } \\ \text { Fitur bahasa } & \text { Penggunaan "I think", I suppose dan } \\ & \text { "In my opinion" }\end{array}$


Letter of opinion dapat merujuk segala surat yang tertulis yang menyatakan opini, baik secara personal maupun profesional. Surat ini dapat dikirimkan ke editor sebuah majalah, yang mempersoalkan konten dari sebuah artikel (personal), atau lebih formal dikirimkan ke pengembang terkait dengan nilai suatu properti (profesional).

Setiap orang memiliki opini dan beberapa dari kita malu untuk mengungkapkannya. Di sinilah letter of opinion diperlukan. Dengan menyampaikan sudut pandang kita dalam menulis, letter of opinion memberikan legitimasi atas perasaan kita.

Letter of opinion seperti buku telepon: memiliki beragam kegunaan. Berikut ini ada beberapa kegunaan yang paling umum:

1. Untuk memuji ataupun mengkritisi sebuah perusahaan

2. Untuk menyampaikan pandangan Anda terhadap suatu isu di masyarakat

3. Untuk mengomentari kebijakan publik

4. Untuk merespon suatu editorial atau artikel

5. Untuk mendukung kandidat atau pejabat yang terpilih lainnya

Semua letter of opinion menyampaikan opini Anda secara jelas dan menyediakan alasan-alasan yang mendukungnya.

Sebuah letter of opinion dapat menyatakan baik gagasan positif maupun negatif, misalnya: Anda dapat menulis kepada sebuah tokoh mengenai pujian atas kasir yang sangat membantu, atau kepada sebuah perusahaan mengenai pujian terhadap sebuah produk atau layanan. Atau, letter of opinion dapat menyatakan pandangan yang sebuah pandagan yang berbeda, sebuah cara yang berbeda dalam melihat isu yang sama. Anda dapat menulis ke sebuah koran, majalah, ataupun stasiun televisi mengenai pandangan editorial mereka. Apapun tujuan Anda atau audiens, berikut ini beberapa saran dalam menulis.

\section{Untuk letters of praise (surat sanjungan):}

a. Nyatakan dengan tegas siapa atau apa yang sedang Anda sanjung.

b. Beri tanggal dari layanan yang dimaksud.

c. Identifikasi karyawan-karyawan yang disanjung dengan nama dan gelar (misal, Jimmy Joe Johnson, clerk).

d. Sertakan nama, alamat, dan nomor telepon Anda.

\section{Untuk letters of dissent (surat perbedaan pendapat):}

a. Sampaikan apa editorial, artikel atau tulisan lainnya yang anda maksud di dalam respon Anda. 
b. Tetap tenang; penyebutan nama akan merugikan Anda.

c. Tetap pada masalah yang dibahas; hindari penyimpangan yang sia-sia.

d. Cantumkan nama, alamat, dan nomor telepon Anda.

\section{Media Pembelajaran}

Media dalam dunia pendidikan menempati posisi yang sangat penting sebagai salah satu komponen dalam pemebelajaran. Tanpa adanya media proses pembelajaran tidak akan mendapatkan hasil maksimal. Menurut Heinich dkk. (dalam Arsyad 2013) kata media merupakan bentuk jamak dari kata "medium". Medium dapat didefinisikan sebagai perantara atau pengantar terjadinya komunikasi dari pengirim menuju penerima.

Definisi media juga diungkapkan oleh Gerlach dan Ely (dalam Arsyad (2013). Ia menyatakan media merupakan manusia, materi atau kejadian yang membangu suatu kondisi atau membuat siswa mampu memperoleh pengetahuan, keterampilan dan sikap. Secara lebih khusus. Pengertian media dalam proses belajar mengajar cenderung diartikan sebagai alat-alat grafis, fotografis, atau elektronis untuk menangkap, memproses, dan menyusun kembali informasi visual atau verbal.

Selain itu Munadi (2013) menyatakan bahwa kata media berasal dari bahasa Latin, yakni medius yang secara harfiah berarti tengah, pengantar, atau perantara. Dalam bahasa Arab, media disebut wasail bentuk jamak dari wasilah yakni sinonim al-wast yang artinya tengah. Kata tengah berarti berada di antara dua sisi, maka disebut juga sebagai perantara (wasilah) atau yang mengantarai kedua sisi tersebut.

Lebih lanjut Munadi (2013) mendefinisikan media pembelajaran sebagai segala sesuatu yang dapat menyampaikan dan menyalurkan pesan dari sumber secara terencana sehingga tercipta lingkungan belajar yang kondusif di mana penerimanya dapat melakukan proses belajar secara efisien dan efektif.

Dari beberapa pendapat tersebut dapat disimpulkan bahwa media pembelajaran merupakan perantara atau pengantar yang dapat menyalurkan pesan dan digunakan dalam kegiatan belajar mengajar oleh pendidik, guna mempermudah tersampainya pesan dan informasi kepada penerima. Media dalam penggunaanya memiliki berbagai macam jenis. Jenis media yang dipilih disesuaikan dengan kebutuhan oleh penggunanya agar tersampaikannya pesan atau informasi. 


\section{Fantastic Card}

Fantastic card adalah selembar kertas tebal atau karton tipis berbentuk persegi panjang dan bergambar yang disajikan dengan tampilan yang menarik dan unik, disetiap kartu terdapat gambar yang berbeda. Gambar tersebut menunjukkan gambar benda atau orang atau tempat. Bila tampilan yang menarik dan unik tersebut dibuka di dalamnya akan tampak sebuah gambar yang akan digunakan siswa sebagai media untuk membuat letter of opinion. Disitulah letak keajaiban kartu tersebut. Sehingga setelah menerima, membuka dan mencermati kartu tersebut siswa akan merasa senang, lebih bersemangat dan mudah menuangkan ide-idenya menjadi sebuah letter of opinion.

Dengan demikian kiranya tepat apabila fantastic card dipergunakan sebagai media pembelajaran dalam menulis letter of opinion karena: (1) fantastic card merupakan benda yang sangat unik dan menarik; (2) fantastic card adalah media yang dapat membantu siswa memunculkan ide-idenya; (3) dengan menggunakan media fantastic card siswa seolah-olah melihat benda atau orang atau tempat seperti aslinya.

Gambar 1.

\section{Gambar Fantastic Card}
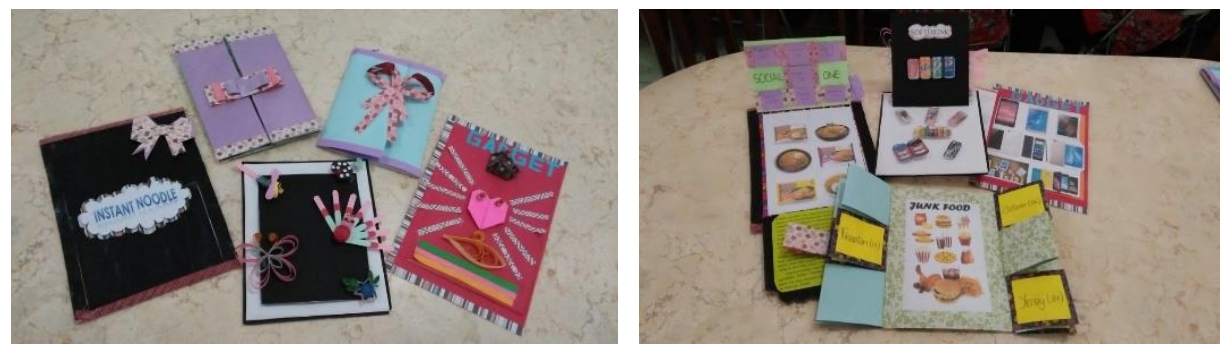

\section{Kerangka Berpikir}

Prosedur penelitian tindakan kelas merupakan siklus dan dilaksanakan sesuai perencanaan tindakan atau perbaikan dari perencanaan tindakan terdahulu. Penelitian ini memerlukan evaluasi awal untuk mengetahui masalah dan menemukan solusinya. Tindakan kelas dilaksanakan dalam bentuk pembelajaran menggunakan media fantastic card disertai dengan pendekatan, model, strategi, dan tehnik. Dalam setiap tindakan peneliti dan observer akan mengamati baik aktivitas maupun sikap siswa selama pembelajaran. Apabila dijabarkan dalam sebuah bagan maka akan didapati kerangka berpikir sebagai berikut: 
Kondisi Awal

Kondisi Akhir

Tindakan Siswa Kelas XI-IPS-2 Rendah<smiles>C1CCCC1</smiles>

$\rightarrow$ Penggunaan Media Fantastic Card sebagai Sarana Menulis Letter of opinion<smiles>C1CCCC1</smiles>

$\rightarrow$ Keterampilan Menulis Letter of opinion pada Siswa Kelas XI-IPS-2 Meningkat

\section{Hipotesis Tindakan}

Hipotesis yang diajukan dalam penelitian tindakan ini adalah" Jika dalam pembelajaran menulis letter of opinion pada siswa kelas XI-IPS-2 SMA Negeri 15 Semarang tahun pelajaran 2017/2018 menggunakan Media Fantastic Card maka keterampilan menulis letter of opinion siswa akan meningkat."

\section{METODE}

Penelitian ini dilaksanakan di SMA Negeri 15, jalan Kedungmundu Raya No. 34 Semarang pada siswa kelas XI-IPS-2. Tempat penelitian dilaksanakan di SMA Negeri 15 Semarang. Penelitian tindakan kelas ini dilaksanakan selama 4 (empat) bulan yaitu pada awal bulan Juli sampai dengan akhir bulan Oktober 2017 pada saat jam pembelajaran yaitu pada hari Kamis. Subyek dalam penelitian ini adalah siswa kelas XI-IPS-2 SMA Negeri 15 Semarang tahun pelajaran 2017/2018 sebanyak 32 orang yang terdiri dari 7 orang siswa putera dan 25 orang siswa puteri.

Sumber data penelitian ini, yaitu sumber data primer dan sumber data sekunder. Sumber data primer pada penelitian ini diambil dari:1) hasil pre-test siswa sebelum tindakan berlangsung; 2) hasil lembar refleksi diri siswa; 3) hasil belajar siswa pada setiap siklus tindakan; 4) hasil observasi tentang sikap belajar siswa pada saat proses pembelajaran; 5) hasil observasi atau pengamatan mengenai kegiatan belajar dan sikap belajar siswa yang dikumpulkan selama tindakan berlangsung dari guru sejawat atau peneliti ahli (expert); dan 6) jurnal guru (teacher's anecdotal record). Sedangkan sumber data sekunder pada penelitian ini diperoleh dari : 1) data mengenai jumlah siswasiswi kelas XI-IPS-2 yang diperoleh dari daftar hadir kelas; 2) data studi 
pustaka yang menunjang penyusunan penelitian ini; dan 3) dokumentasi berupa foto- foto tentang kegiatan siswa selama siklus I dan II berlangsung.

Tehnik yang digunakan ada 2 (dua) macam yaitu tes dan non-tes. Tehnik tes yang digunakan untuk mengukur kemajuan hasil belajar siswa adalah ulangan harian dan lembar rubrik penilaian produk magic card. Sedangkan tehnik non-tes berupa observasi perilaku belajar siswa selama proses pembelajaran berlangsung serta lembar refleksi diri siswa setelah setiap siklus selesai dilaksanakan.

Alat pengumpulan data yang digunakan dalam penelitian ini meliputi: lembar soal pre-test sebelum siklus I tentang menulis letter of opinion tanpa menggunakan media fantastic card; lembar rubrik penilaian (rubric assessment sheet) yang dipergunakan untuk mengukur keterampilan siswa dalam menulis letter of opinion menggunakan media fantastic card yang dipergunakan guru peneliti untuk menilai produk; lembar refleksi diri siswa dipergunakan untuk menggali kesulitan-kesulitan apakah yang dihadapi siswa dalam proses pembelajaran siklus I; lembar pengamatan dipergunakan oleh guru sejawat untuk mencatat aktivitas dan tingkat motivasi siswa selama proses pembelajaran berlangsung; studi pustaka tentang peningkatan keterampilan menulis letter of opinion menggunakan Media fantastic card untuk mendukung penelitian ini, dokumentasi yang berupa foto-foto tentang kegiatan siswa pada setiap siklus pembelajaran.

Untuk menganalisis data hasil penelitian peneliti menggunakan metode: (1) deskriptif, yaitu digunakan untuk upaya memecahkan masalah atau menjawab permasalahan yang dihadapi. (2) kualitatif, yaitu penggambaran dengan kata-kata atau kalimat yang dipisahkan dengan katagori analisis data deskriptif kualitatif yaitu analisis data yang tidak dapat diukur melalui perhitungan dengan angka-angka melainkan dengan menggunakan kata-kata.

Validasi Penelitian Tindakan Kelas ini menggunakan trianggulasi sumber dan triangulasi metode. Triangulasi sumber data berasal dari guru kelas, siswa dan guru teman sejawat sebagai kolaborator. Sedangkan triangulasi metode yaitu data dari pengumpulan dokumen, hasil obeservasi dan hasil tes tertulis.

Akhir dari pada penelitian tindakan kelas ini adalah tercapainya peningkatan keterampilan menulis letter of opinion dan perubahan dalam sikap belajar siswa 
Tabel 1:

Predikat hasil antar siklus

\begin{tabular}{|c|c|c|}
\hline No & $\begin{array}{c}\text { Nilai } \\
\text { Persentase }\end{array}$ & Predikat \\
\hline 1 & $86-100$ & Amat Baik \\
\hline 2 & $76-85$ & Baik \\
\hline 3 & $70-75$ & Cukup \\
\hline 4 & $60-69$ & Kurang \\
\hline 5 & $\leq 59$ & Kurang Sekali \\
\hline
\end{tabular}

Prosedur penelitian tindakan kelas (PTK) ini di rancang untuk dilaksanakan dalam 2 siklus dimana siklus I dilaksanakan dalam 1 kali pertemuan, siklus II dilaksanakan juga dalam 1 kali pertemuan, dengan alokasi waktu setiap pertemuan 2X45 menit (90 menit). Setiap siklus terdiri dari 4 tahapan yang harus di jalani yaitu perencanaan, pelaksanaan/ tindakan, pengamatan/ observasi dan refleksi.

\section{Siklus I}

\section{1) Perencanaan (Planning)}

Tahap Perencanaan dimulai dari (1) merencanakan RPP dan skenario pembelajaran siklus I untuk dua kali pertemuan dengan alokasi waktu 2 X45 menit per pertemuan; (2) Menyiapkan materi letter of opinion yang akan disajikan untuk siswa; (3) Mempersiapkan materi ;(4) Menyiapkan media fantastic card yang akan digunakan siswa untuk membantu menulis letter of opinion; (5) Menyusun soal-soal evaluasi yang berkaitan dengan teks yang telah disiapkan; (6) Menyiapkan instrumen penilaian.

\section{2) Pelaksanaan (Acting)}

Kegiatan pembelajaran letter of opinion dilakukan terlebih dahulu sehingga siswa mendapatkan konsep letter of opinion dengan jelas. Guru memberikan pemahaman kepada siswa tentang social function, generic stucture dan language features dari letter of opinion. Selanjutnya guru memberi penjelasan tentang media fantastic card dan penggunaan media fantastic card yang akan digunakan siswa dalam upaya peningkatan keterampilan menulis letter of opinion. Setelah memberikan penjelasan secara detail tentang letter of opinion dan media fantastic card, guru memberikan contoh letter of opinion dan bagaimana cara menulis letter of opinion. Setelah kegiatan tanya jawab antara guru dan siswa tentang menulis letter of opinion berlangsung, siswa mulai melakukan perintah guru menuliskan letter of opinion berbahasa Inggris dengan 
menggunakan media fantastic card. Pembelajaran dilakukan sesuai acuan Kurikulum 2013 atau K-13.

\section{HASIL DAN PEMBAHASAN}

\section{Deskripsi Kondisi Awal}

Pada kondisi awal belajar guru melakukan pra siklus (pre test) yaitu menulis letter of opinion tanpa menggunakan fantastic card. Pra siklus dilakukan untuk mengetahui kondisi awal siswa sebelum dilakukan tindakan siklus I.

Hasil dari refleksi kondisi awal hasil belajar siswa kelas XI-IPS-2 SMA Negeri 15 Semarang sebelum dilakukan tindakan pada siklus I didapatkan hasil sebagai berikut :

Tabel 2:

Hasil Tes dalam Pra Siklus

\begin{tabular}{|c|c|c|c|c|}
\hline No & Nilai & $\begin{array}{c}\text { Jumlah } \\
\text { Responden }\end{array}$ & Persentase $\%$ & Keterangan \\
\hline 1. & $86-100$ & 0 & 0 & Amat Baik \\
\hline 2. & $76-85$ & 7 & 21,88 & Baik \\
\hline 3. & $70-75$ & 10 & 31,25 & Cukup \\
\hline 4. & $60-69$ & 13 & 40,63 & Kurang \\
\hline 5. & $0-59$ & 2 & 6,25 & Kurang Sekali \\
\hline & Jumlah & 32 & 100 & \\
\hline
\end{tabular}

Dari 32 siswa yang mengikuti tes pra siklus, tidak ada siswa yang mendapatkan nilai amat baik atau $0 \%, 7$ siswa atau 21,88\% mendapatkan nilai baik, 10 siswa atau 31,25\% mendapatkan nilai cukup sedangkan 13 siswa atau 40,63\% mendapatkan nilai kurang sedangkan 2 siswa atau 6,25\% mendapatkan nilai kurang sekali. Pada tabel diatas diketahui bahwa Ketuntasan Belajar Klasikal hanya 53,13\% dimana persentase ini masih kurang dari indikator ketuntasan belajar minimal yaitu 70\%. 


\section{Deskripsi Hasil Siklus I}

Dari hasil tes pra siklus yang ditunjukkan oleh tabel diatas bahwa persentase Ketuntasan Belajar Klasikal masih sangat kurang oleh sebab itu peneliti mengambil tindakan pada siklus I yaitu dengan memberikan penjelasan secara detail tentang materi letter of opinion. Pada siklus I siswa menulis letter of opinion tanpa menggunakan media fantastic card. Siklus I dilakukan untuk mengetahui sejauh mana peningkatan keterampilan siswa dalam menulis letter of opinion tanpa menggunakan media fantastic card. berikut:

Dari siklus I diperoleh hasil seperti terlihat pada tabel 3 sebagai

Tabel 3:

Hasil Tes dalam Siklus I

\begin{tabular}{|c|c|c|c|c|}
\hline No & Nilai & $\begin{array}{c}\text { Jumlah } \\
\text { Responden }\end{array}$ & $\begin{array}{c}\text { Persentase } \\
\mathbf{\%}\end{array}$ & Keterangan \\
\hline 1. & $86-100$ & 0 & 0 & Amat Baik \\
2. & $76-85$ & 9 & 28,13 & Baik \\
3. & $70-75$ & 12 & 37,50 & Cukup \\
4. & $60-69$ & 11 & 34,36 & Kurang \\
5. & $0-59$ & 0 & 0 & Kurang Sekali \\
\hline \multicolumn{2}{r}{ Jumlah } & $\mathbf{3 2}$ & $\mathbf{1 0 0}$ & \\
\hline
\end{tabular}

Berdasarkan Tabel 3 di atas dapat diketahui bahwa keterampilan siswa dalam menulis letter of opinion pada siklus I mengalami peningkatan jika dibandingkan dengan hasil belajar pada pra siklus. Ada 9 siswa atau 28,13\% mendapatkan nilai baik, 12 siswa atau 37,50\% mendapatkan nilai cukup, 11 siswa atau $34,36 \%$ mendapatkan nilai kurang sedangkan 0 siswa mendapatkan nilai kurang sekali. Dari tabel 3 diatas menunjukkan bahwa Ketuntasan Belajar Klasikal mencapai 65,63\%. Namun penulis masih berusaha untuk lebih meningkatkan keterampilan siswa dalam menulis letter of opinion. Penulis mencoba berkonsultasi dengan para observer dengan cara meminta pendapat dan juga masukan untuk lebih meningkatkan keterampilan siswa dalam menulis letter of opinion. Setelah mendapat saran, masukan dan motivasi dari para observer, penulis melangkah ke siklus II.

\section{Deskripsi Hasil Siklus II}

Skenario pembelajaran siklus II memiliki alur yang sama dengan skenario pembelajaran siklus I, namun pada siklus II guru peneliti menggunakan media pembelajaran berupa fantastic card, dengan harapan dapat meningkatkan keterampilan siswa dalam menulis letter of opinion. Pada 
siklus II perbaikan-perbaikan berdasarkan catatan dari observer dilakukan untuk lebih meningkatkan kualitas pembelajaran dan hasil prestasi siswa dalam menulis letter of opinion pada mata pelajaran Bahasa Inggris dengan menggunakan media fantastic card di kelas XI-IPS-2 SMA Negeri 15 Semarang. berikut:

Hasil dari siklus II diperoleh seperti terlihat pada tabel 4 sebagai

Tabel 4:

Hasil Tes dalam Siklus II

\begin{tabular}{|c|c|c|c|c|}
\hline No & Nilai & $\begin{array}{c}\text { Jumlah } \\
\text { Responden }\end{array}$ & $\begin{array}{c}\text { Persentase } \\
\mathbf{\%}\end{array}$ & Keterangan \\
\hline 1. & $86-100$ & 3 & 9,38 & Amat Baik \\
2. & $76-85$ & 13 & 40,63 & Baik \\
3. & $70-75$ & 14 & 31,25 & Cukup \\
4. & $60-69$ & 2 & 18,75 & Kurang \\
5. & $0-59$ & 0 & 0 & Kurang Sekali \\
\hline \multicolumn{2}{r}{ Jumlah } & $\mathbf{3 2}$ & $\mathbf{1 0 0}$ & \\
\hline
\end{tabular}

Berdasarkan Tabel di atas dapat diketahui bahwa keterampilan siswa dalam menulis letter of opinion dengan menggunakan media fantastic card mengalami peningkatan drastis. Dari 32 siswa yang diteliti ada 3 siswa atau 9,38\% mendapatkan nilai amat baik, 13 siswa atau 40,63\% mendapatkan nilai baik sedangkan hanya 14 siswa atau 31,25\% mendapatkan nilai cukup. Dari tabel 2 diatas menunjukkan bahwa Ketuntasan Belajar Klasikal mencapai 93,75\%. Pada siklus II tidak ada siswa yang mendapatkan nilai kurang sekali. tabel 5:

Rekapitulasi perbandingan hasil belajar antar siklus dapat dilihat pada

Tabel 5:

Rekapitulasi Perbandingan Antar Siklus

\begin{tabular}{|c|c|c|c|}
\hline \multirow{2}{*}{ URAIAN } & \multicolumn{3}{|c|}{ NILAI } \\
\cline { 2 - 4 } & PRA SIKLUS & SIKLUS I & SIKLUS II \\
\hline Rata-rata & 70,5 & 73,03 & 79,84 \\
\hline Tertinggi & 80 & 83 & 90 \\
\hline Terendah & 60 & 68 & 69 \\
\hline
\end{tabular}


Diagram 1:

Perbandingan Prosentase Keterampilan Siswa dalam Menulis Letter of Opinion dengan Menggunakan Fantastic Card

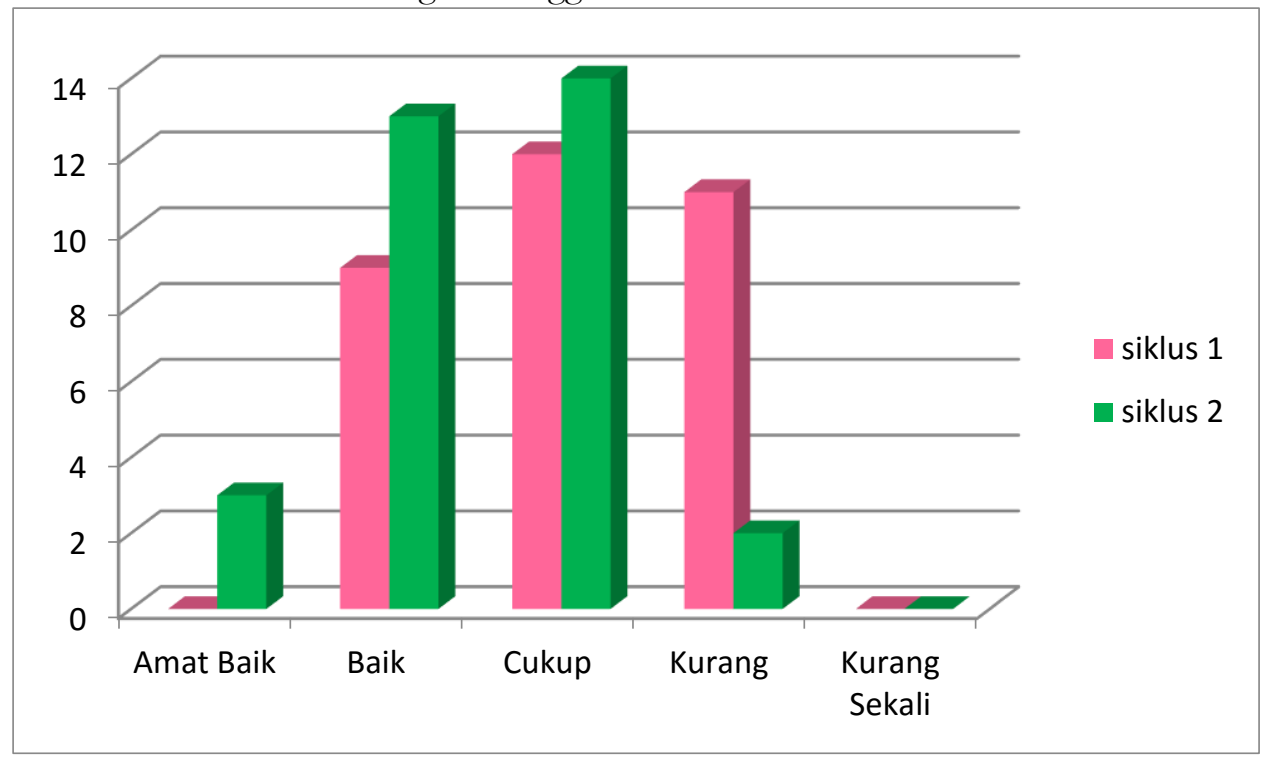

Keterangan:

Siklus I : 0 siswa menempati kategori amat baik ; 9 siswa menempati kategori baik ; 12 siswa menempati kategori cukup ; 11 siswa menempati kategori kurang dan o siswa menempati kategori kurang sekali

Siklus II : 3 siswa menempati kategori amat baik ; 13 siswa menempati kategori baik ; 14 siswa menempati kategori cukup ; 2 siswa menempati kategori kurang dan o siswa menempati kategori kurang sekali

Berdasarkan data di atas dapat disimpulkan bahwa:

1. Nilai rata-rata keterampilan siswa dalam menulis letter of opinion pada siklus I meningkat mencapai nilai 73,03 yang semula pada pra siklus keterampilan siswa dalam menulis letter of opinion mendapatkan nilai rata-rata 70,5. Sedangkan nilai rata-rata pada siklus II mununjukkan bahwa keterampilan siswa dalam menulis letter of opinion dengan menggunakan media magic card meningkat drastis yaitu mencapai 79,84.

2. Nilai tertinggi keterampilan siswa dalam menulis letter of opinion pada siklus I meningkat mencapai nilai 83 yang semula pada pra siklus mendapatkan nilai tertinggi 80 . Sedangkan nilai tertinggi pada siklus II mununjukkan bahwa keterampilan siswa dalam menulis letter of opinion dengan menggunakan media fantastic card meningkat drastis yaitu mencapai 90 . 
3. Demikian juga pada pencapaian nilai terendah keterampilan siswa dalam menulis letter of opinion meningkat hingga mencapai 68 yang semula pada pra siklus nilai terendah mencapai 60. Sedangkan nilai terendah pada siklus II menunjukkan bahwa keterampilan siswa dalam menulis letter of opinion dengan menggunakan media fantastic card meningkat yaitu mencapai 69.

\section{Hasil Non Tes}

Hasil non tes mencakup hasil yang diperoleh dari observasi berupa angket. Hasil observasi menunjukkan bahwa siswa merasa lebih senang, semangat, tertarik dan termotivasi sehingga menjadikan siswa lebih terampil dalam menulis letter of opinion dengan menggunakan media fantastic card. Siswa merasa sangat terbantu dalam menulis letter of opinion dengan menggunakan media fantastic card.

Dari angket yang ditujukan pada 32 siswa diperoleh informasi bahwa pada siklus I ada 17 siswa atau 53,13\% siswa tampak antusias dalam menulis letter of opinion. Sebanyak 15 siswa atau 46,87\% siswa tampak berkonsentrasi dalam menulis letter of opinion tanpa menggunakan media magic card. Sebanyak 15 siswa atau 46,87\% siswa tampak kreatif sedangkan sebanyak 20 siswa atau $62,50 \%$ siswa tampak tenang atau tidak gaduh selama pembelajaran.

Dari hasil tersebut kami sajikan dalam tabel sebagai berikut:

Tabel 6:

Aktifitas siswa selama pembelajaran Siklus I

\begin{tabular}{|c|c|c|c|}
\hline No & Jumlah Responden & $\begin{array}{c}\text { Persentase } \\
\mathbf{( \% )}\end{array}$ & Keterangan \\
\hline 1 & 17 & 53,13 & Antusias \\
2 & 15 & 46,87 & Konsentrasi \\
3 & 15 & 46,87 & Kreatif \\
4 & 20 & 62,50 & Tenang \\
\hline
\end{tabular}

Pada siklus II berdasarkan tabel 7 dapat terbaca bahwa aktifitas siswa selama pembelajaran mengalami peningkatan jumlah responden. Ada 27 siswa atau $84,37 \%$ tampak antusias dalam menulis teks descriptive menggunakan media magic card. Sebanyak 20 siswa atau $62,50 \%$ siswa tampak berkonsentrasi dalam menulis teks descriptive menggunakan media magic card. Sebanyak 22 siswa atau 68,75 \% siswa tampak kreatif dalam menulis teks descriptive menggunakan media magic card. Sedangkan 
sebanyak 24 siswa atau 75,00 \% siswa tampak tenang atau tidak gaduh selama pembelajaran.

Dari hasil tersebut kami sajikan dalam tabel sebagai berikut:

Tabel 7:

Aktifitas siswa selama pembelajaran Siklus II

\begin{tabular}{|c|c|c|c|}
\hline No & Jumlah Responden & $\begin{array}{c}\text { Persentase } \\
(\mathbf{\%})\end{array}$ & Keterangan \\
\hline 1 & 27 & 84,37 & Antusias \\
2 & 20 & 62,50 & Konsentrasi \\
3 & 22 & 68,75 & Kreatif \\
4 & 24 & 75,00 & Tenang \\
\hline
\end{tabular}

Diagram 2.

Perkembangan Hasil Belajar

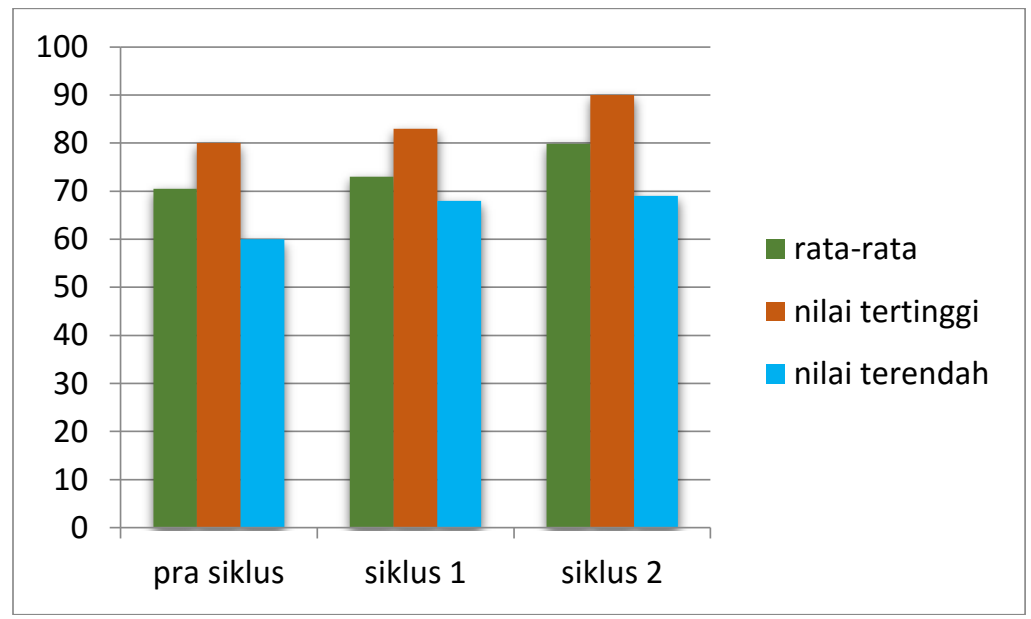

Keterangan

- Pra siklus nilai rata-rata 70,5; nilai tertinggi 80 ; dan nilai terendah 60

- Siklus I nilai rata-rata 73,03 ; nilai tertinggi 83 ; dan nilai terendah 68

- Siklus II nilai rata-rata 79,84 ; nilai tertinggi 90 ; dan nilai terendah 69 


\section{Pembahasan Hasil}

Keterampilan siswa dalam menulis letter of opinion pada siklus I diperoleh hasil secara klasikal sebanyak 9 siswa atau sebesar 28,13\% menempati kategori baik. Sedangkan 12 siswa atau 37,50\% menempati kategori cukup. Sehingga siswa yang berhasil mencapai kriteria ketuntasan minimal ada 21 siswa atau 65,63\%.

Jika dibandingkan dengan keberhasilan siswa pada pra siklus yaitu hanya ada 7 siswa atau 21,88\% siswa menempati kategori baik. Siswa yang berhasil mencapai kriteria ketuntasan minimal hanya ada 17 siswa atau $53,13 \%$.

Berdasar hasil pengamatan para observer dan learning log siswa, pada siklus I, suasana pembelajaran yang menyenangkan dan kondusif sejalan dengan kemampuan dan kepribadian guru. Dengan kemampuan dan kepribadian guru yang baik akan meningkatkan kualitas, semangat dan motivasi siswa untuk lebih terampil dalam menulis letter of opinion.

Setelah siklus I, berdasarkan angket siswa diketahui bahwa terjadi peningkatan dalam kualitas pembelajaran dan peningkatan hasil belajar. Hal ini disebabkan karena antusias, semangat dan motivasi siswa untuk mencapai prestasi yang tinggi dan mendapat nilai yang tinggi.

Pada siklus II terjadi peningkatan yang sangat drastis, baik dalam kualitas pembelajaran maupun peningkatan hasil belajar. Peningkatan kualitas pembelajaran terlihat dari meningkatnya semangat dan motivasi siswa dalam menulis letter of opinion. Siswa tampak lebih kreatif dalam menuangkan ideidenya sehingga terbentuk letter of opinion yang bermakna dan berkualitas

Peningkatan kualitas pembelajaran tersebut signifikan dengan kemampuan dan kepribadian guru mata pelajaran. Apabila guru tidak memiliki kemampuan pedagogis yang baik dan tidak memiliki kepribadian yang baik sangat mungkin menyebabkan menurunnya kualitas pembelajaran. Sebaliknya guru yang memiliki kemampuan pedagogis dan kepribadian yang baik dapat meningkatkan kualitas pembelajaran.

Keterampilan siswa dalam menulis letter of opinion dengan menggunakan media fantastic card pada sikluas II merupakan perbaikan dan peningkatan dari siklus I. Kelemahan dan kekurangan siswa dalam menulis letter of opinion dengan menggunakan media fantastic card pada siklus II baik dari guru maupun siswa sudah tidak tampak. Peningkatan kualitas pembelajaran ditandai dengan meningkatnya kreatifitas, semangat dan motivasi siswa, serta suasana belajar yang menyenangkan. Hal inilah yang menyebabkan keterampilan siswa dalam menulis letter of opinion dengan 
menggunakan media fantastic card pada siklus II mengalami peningkatan yang drastis.

Jika dibandingkan dengan hasil tes pada siklus I yang rata-rata 73,03 , maka rata-rata nilai hasil tes pada siklus II yang mencapai 79,84 berarti mengalami kenaikan sebesar 6,81 atau 6,81\%. sedang dibanding dengan hasil belajar pada pra siklus yang rata-ratanya 70,5, maka hasil belajar pada siklus II mengalami peningkatan sebesar 9,34\%. Dengan demikian keterampilan siswa dalam menulis letter of opinion dengan menggunakan fantastic card pada siklus II sebagian besar siswa yaitu $93,75 \%$ benar-benar terampil menulis letter of opinion.

\section{KESIMPULAN}

\section{Simpulan}

1. Keterampilan menulis letter of opinion pada pelajaran bahasa Inggris dengan menggunakan media fantastic card di Kelas XI-IPS-2 SMA Negeri 15 Semarang tahun 2017/2018 meningkat.

2. Peningkatan kualitas pembelajaran dapat terlihat dari meningkatnya rasa senang, semangat dan motivasi siswa dalam keterampilan menulis letter of opinion dengan menggunakan media fantastic card. Guru juga bisa tampil lebih percaya diri karena bisa membuat situasi kelas menjadi lebih menyenangkan, bersemangat dan termotivasi.

3. Keterampilan menulis letter of opinion dengan menggunakan media fantastic card di kelas XI-IPS-2 SMA Negeri 15 Semarang dapat meningkatkan prestasi hasil belajar. Keterampilan siswa dalam menulis letter of opinion pada pra siklus rata-ratanya adalah 70,5, sedangkan pada siklus I ratarata nilai mencapai 73,03 dan pada siklus II rata-rata nilai mencapai 79,84. Peningkatan ketuntasan keterampilan siswa dalam menulis letter of opinion tanpa menggunakan media fantastic card pada siklus I sebesar 65,63\% dan pada siklus II mencapai peningkatan yang drastis sebesar 93,75\%.

\section{Saran/Rekomendasi}

1. Bagi para guru mata pelajaran Bahasa Inggris, hendaknya perlu menggunakan media pembelajaran sebagai upaya meningkatkan kemampuan siswa dalam menguasai berbagai keterampilan di kelas. 
2. Para guru Bahasa Inggris perlu berlatih untuk mulai melaksanakan penelitian tindakan kelas sebagai syarat pengembangan profesi seorang guru sehingga mampu mengatasi permasalahan pembelajaran Bahasa Inggris di kelas.

\section{DAFTAR PUSTAKA}

Anni, C. T. (2004). Psikologi Belajar. Semarang: CV. IKIP Semarang Press. Arsyad, A. (2013). Media Pembelajaran. Depok: PT. Rajagrafindo Persada. Bahri \& Aswan. (2006). Strategi Belajar Mengajar. Jakarta: PT Rineka Cipta. Churchil, G. A. (1991). Marketing Research Metodological Foundations. New York: The Dryden Press.

Daryanto. (2015). Media Pembelajaran. Bandung: PT Sarana Tutorial Nurani Sejahtera.

Departemen pendidikan Nasional. Peraturan Menteri Pendidikan Nasional No. 22 Tabun 2006. Tentang Standart Isi untuk Satuan Pendidikan Dasar dan Menengah.

Djamarah, S. B., \& Zain, A. (2002). Strategi Belajar Mengajar. Jakarta : PT. Rineka Cipta.

Hakim, T. (2002). Belajar Secara Efektif. Jakarta: Penerbit Puspa Swara.

Harisiati, T. (1999). Penelitian Tindakan Sebagai Aplikasi Metode Ilmiah dan Pemecahan Masalah Pembelajaran Bahasa. Dalam Seminar FPBS IKIP Malang.

Manser, M. H. (1991). Oxford Learner's Pocket Dictionary. New York: Oxford University Press.

Munadi, Y. (2013) Media Pembelajaran. Jakarta: Referensi.

Peraturan Mentri Pendidikan Nasional No. 22 Tahun 2006. Tentang Standart Isi untuk Satuan Pendidikan Dasar dan Menengah.

Purwanto, N.. (1984). Prinsip-prinsip dan Teknik Evaluasi Pengajaran. Jakarta: Ramadia.

Putra, N. (2015). Research \& Development, Jakarta: Rajawali Press.

Riduan. (2004). Belajar mudah Penelitian untuk Guru-Karyawan dan Peneliti Pemula. Alfabeta: Bandung.

Rustana, C. (2002). Pembelajaran dan Pengajaran Kontekstual. Jakarta: Direktorat Pendidikan Dasar dan Menengah.

Siregar, E., \& Hartini. (2014). Teori Belajar dan Pembelajaran. Ciawi Bogor: Ghalia Indonesia.

Slameto. (2010). Belajar dan Faktor-Faktor Yang Mempengarubi, Jakarta: Rineka Cipta.

Spencer, D. H. (2005). Guided Composition Exercises. Yogyakarta: Kanisius.

Sudaryo, dkk. (1990). Strategi Belajar Mengajar. Semarang : IKIP Press.

Suharsimi, A. (1993). Prosedur Penelitian Suatu Pendekatan Praktek. Jakarta: PT. Rineka Cipta. 
Sujana, N., \& Rifai, A. (2009). Media Pengajaran: Penggunaan dan Pembuatannya. Bandung: Penerbit Sinar Baru Algensindo.

Sulaiman D. (1988). Teknologi / Metodologi Pengajaran. Depdikbud Ditjen Dikti Proyek Pengembangan LPTK: Jakarta.

Trianto. (2007). Metode-metode Pembelajaran Inovatif Berorientasi Konstruktivistik. Jakarta: Prestasi Pustaka.

Winataputra, U. S., dkk. (2007). Teori Belajar dan Pembelajaran. Jakarta: Universitas Terbuka. 